\title{
Tyrphostin B46
}

National Cancer Institute

\section{Source}

National Cancer Institute. Tyrphostin B46. NCI Thesaurus. Code C1675.

A potent inhibitor of epidermal growth factor receptor kinase autophosphorylation. $(\mathrm{NCl})$ 